\begin{tabular}{c|c}
$\begin{array}{c}\text { МОНГОлОВЕДЕНИЕ } \\
\text { (Монгол судлал) }\end{array}$ & \\
(Mongolian Studies) (Elista) & ISSN 2500-1523 (Print) \\
Vol. 12, Is. 3, pp. 574-580, 2020 & ISSN 2712-8059 (Online) \\
DOI: 10.22162/2500-1523-2020-3-574-580 & Published since 2002 \\
\hline
\end{tabular}

\title{
РЕЦЕНЗИЯ
}

УДК $294.3(517.3)$

DOI: $10.22162 / 2500-1523-2020-3-574-580$

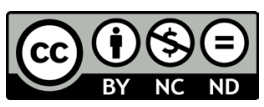

\section{Рец.: Ванчикова Ц. П. Буддизм в Монголии: история, духовенство, монастыри. Иркутск: Оттиск, 2019. 292 с.}

Сергей Львович Кузьмин ${ }^{1}$
${ }^{1}$ Институт востоковедения РАН (д. 12, ул. Рождественка,108031 Москва, Российская Федерация) доктор исторических наук, кандидат биологических наук, ведущий научный сотрудник
iD 0000-0001-9544-1359. E-mail: ipe51@yahoo.com

Для цитирования: Кузьмин С. Л. Рец.: Ванчикова Ц. П. Буддизм в Монголии: история, духовенство, монастыри. Иркутск: Оттиск, 2019. 292 с. // Монголоведение. 2020. Т. 12. № 3. C. 573-579. DOI: 10.22162/2500-1523-2020-3-574-580

(C) КалмНЦ РАН, 2020

(C) Кузьмин С. Л., 2020

UDC 294.3 (517.3)

DOI: $10.22162 / 2500-1523-2020-3-574-580$

\section{Book Review: Vanchikova Ts. P. Buddhism in Mongolia: History, Clergy, Monasteries. Irkutsk: Ottisk, 2019. 292 p. (In Russ.)}

\section{Sergius L. Kuzmin ${ }^{1}$}

\footnotetext{
${ }^{1}$ Institute of Oriental Sciences of the RAS (12, Rozhdestvenka St., Moscow 108031, Russian Federation)

Dr. Sc. (History), Cand. Sc. (Biology), Leading Research Associate

iD 0000-0001-9544-1359. E-mail: ipe51@yahoo.com
}

For citation: Kuzmin S. L. Book Review: Vanchikova Ts. P. Buddhism in Mongolia: History, Clergy, Monasteries. Irkutsk: Ottisk, 2019. 292 p. (In Russ.). Mongolian Studies (Elista). 2020. Vol. 12. No. 3. Pp. 574-580. (In Russ.). DOI: 10.22162/2500-1523-2020-3574-580

(C) KalmSC RAS, 2020

(C) Kuzmin S. L., 2020 


\section{Рецензия}

Изучение буддизма Монголии имеет давнюю историю, в основном, со времен работ А. М. Позднеева [Позднеев 1880; Позднеев 1887]. Монгольские и российские работы социалистического периода посвящены в основном взаимодействию буддийской церкви страны с властями и обществом, решению «ламского вопроса» и т. п. (например: [Пүрэвжав, Дашжамц 1965; Скрынникова 1988]).

После 1990-х гг., когда в Монголии и России в результате реформ произошли значительные перемены в обществе, появились (и продолжают появляться) работы, основанные на деидеологизированной методологии, в том числе опирающиеся на ранее не введенные в научный оборот религиозные и исторические источники (например, [Батсайхан 2011; Монголын сүм 2009; Монголын сүм 2012; Мягмарсамбуу 2014; Кузьмин 2016]). Вместе с тем представляет интерес обзор и анализ истории буддизма в Монголии от времени его проникновения в этот регион и до наших дней, с опорой на источники.

Такое исследование представляет собой монография Ц. П. Ванчиковой. Работа состоит из введения, 12 глав, сгруппированных в три раздела, заключения, списка литературы и источников, приложения, именного указателя [Ванчикова 2019].

Во «Введении» дается краткий очерк истории изучения проблемы с XIX в. до наших дней. Отмечается важность выявления и составления сводных каталогов трудов монгольских ученых лам, переводов с тибетского на монгольский язык ряда их сочинений, проекта перевода на кириллицу Ганджура и Данджура. Отмечается, что некоторые вопросы еще находятся в стадии разработки. Сформулирована цель монографии: краткий очерк истории буддизма Монголии, описание жизни и деятельности некоторых выдающихся лам, представление сведений о наиболее крупных буддийских монастырях, ознакомление читателя с малоизученными или ранее неизвестными архивными материалами по монастырям.

В части 1-й «История» глава 1 «Ранний период, период Чингис-хана, единого Монгольского государства» представляет интересный обзор формирования буддизма на землях монголов до времен становления Великого Монгольского государства. Отмечается, что в монгольских и тибетских источниках указана древность распространения буддизма на данной территории - со времен царя Ашоки из династии Маурьев (273-232 гг. до н. э.). Современные монгольские исследователи придерживаются периодизации истории буддизма в Монголии на три этапа, согласно Зава Дамдину: ранний — от эпохи хунну до Чингис-хана, средний — от Чингис-хана и Юань (в форме тибетской школы Сакья), третий — c XVI в. (в форме школы Гэлуг). Эта периодизация подтверждается и археологическими данными.

В главе 2 «Буддизм в период Монгольской империи, преемников Чингис-хана, монгольской империи Юань», в разделе 2.1. о Хубилай-хане и деятельности тибетских лам при монгольских ханах показано, что во времена Чингис-хана буддизм проникал в Монголию благодаря тибетским ламам, но не имел там успеха до воцарения Хубилай-хана. Автором дается краткая история принятия буддизма Хубилаем, распространение этой религии в его империи. На основе летописи «Цагаан түүх» («Белая история») описываются основы 
сформулированной в тот период концепции «двух законов» — ханской власти и буддийской религии, сыгравшей важную роль в монгольском мире и унаследованной маньчжурскими императорами. Описана деятельность Пагба-ламы.

Глава 3 «Буддизм в минский период» довольно короткая, но дает хорошее представление о буддизме в Монголии того времени («темного» периода монгольской истории) и влиянии на него китайской империи Мин.

В главе 4 «Буддизм в XVI в. - 1911 г.», в разделе 4.1. о деятельности тумэтского Алтан-хана и Хутухтай Сэцэн-хунтайджи содержится анализ причин распространения буддизма школы Гэлуг среди монголов. Справедливо указывается, что «восстановление буддизма в роли государственной религии монголов было связано с неоднократными попытками возрождения Монгольской империи» [Ванчикова 2019: 34].

Особое внимание уделено биографиям и деятельности Алтан-хана и Хутухтая Сэцэн-хунтайджи, с которыми связано принятие буддизма Гэлуг монголами. Раздел 4.2. о деятельности халхаских Абатай-хана и Лигдэн-хана посвящен начальному этапу распространения Гэлуг в Халхе. Раздел 4.3. посвящен законам и уложениям XVII-XVIII вв., касающимся буддизма и причинам успеха его распространения в Монголии.

Глава 5 «Буддизм в маньчжурский период» начинается разделом о политике маньчжуров в отношении буддийской церкви, где особое внимание уделено политическому значению, которое придавали маньчжуры распространению буддизма среди монголов. Дан обзор некоторых маньчжурских нормативных актов на эту тему. В разделе 5.2. «Шабинары (создание института шабинаров)» содержится описание институции шабинаров - учеников высших лам, работавших на их монастыри. Обсуждаются изменения подхода цинских властей к этой институции. Интересны сведения о том, что был введен запрет на прием в шабинары дворян (но источник этой информации не указан). Раздел 5.3. об истории переводческой деятельности по смыслу близок к следующему разделу о переводах буддийского канона на монгольский язык. В последнем приводятся данные о монгольских переводах Ганджура и Данджура в цинский период, которые представляют особый интерес.

Глава 6 «Буддизм в 1911-1945 гг.» начинается разделом 6.1. «Буддийская церковь в 1911-1921 гг.», который посвящен роли буддизма в становлении теократического Монгольского государства. Автор делает важный и верный вывод, что «монгольская теократическая монархия, созданная в 1911 г. в результате национально-освободительного движения, была хотя и недолгим, но важным этапом в истории завоевания государственной независимости» [Ванчикова 2019: 66].

Следующий раздел - о буддизме в 1921-1945 гг. и законе об отделении дел религии от государства 1926 г. - посвящен взаимоотношениям буддийской церкви Монголии с Монгольской народной (позже - народно-революционной) партией и государством. Раздел 6.3. о создании Церковной администрации (Шашны захирга) и ее уставе посвящен функционированию Церковной администрации - структуры, созданной по указаниям МНРП для контроля над монастырями. В следующем разделе проанализированы репрессии против буддийской церкви в контексте политики Коминтерна; в хронологическом по- 


\section{Рецензия}

рядке приводится история подавления буддизма в МНР. Раздел 6.5. о законе об отделении дел религии от дел государства 1934 г. и апогее антирелигиозной борьбы посвящен периоду, когда буддизм в МНР был уничтожен государством.

Глава 7 «Буддизм в 1944 - конце 1980-х гг.» начинается разделом 7.1. о возобновлении деятельности монастыря Гандантегченлин в 1944 г. Этот краткий раздел весьма полезен, поскольку обобщает имеющиеся фрагментарные данные об обстоятельствах (пере)открытия в 1944 г. монастыря Гандантегченлин - единственного функционировавшего с тех пор в МНР. Следующий раздел посвящен уставу монастыря Гандантегченлин 1944 г. В разделе 7.4. обсуждаются деятельность монастыря Гандантегченлин в конце 1960 - начале 1970-х гг. и установление его международных связей. Приводятся сведения о взаимодействии духовных управлений буддистов МНР и СССР. Раздел 7.5. посвящен созданию образовательного буддийского института им. Занабазара для монахов.

Глава 8 «Буддизм в 1980-е - 2017 гг.» поделена на несколько разделов: 8.1. «Буддизм в 1980-1990-е гг.», 8.2. «Конституция Монголии 1992 г., Закон об отношениях между государством и религией 1993 г. и другие законодательные акты», 8.3. «Религиозная ситуация в Монголии. О возрождении традиционных религий. Восстановление и строительство буддийских монастырей» (с подразделом 8.3.1. «Распространение новых религий и новых религиозных организаций»). В этой главе проанализировано положение буддизма преимущественно в период после краха социализма в Монголии, а также современная религиозная ситуация.

В части 2-й «Буддийское духовенство Монголии» глава 1 «О формировании монашеской общины в буддийских дацанах» представляет собой краткий очерк формирования буддийских общин от Древней Индии до средневековой Монголии и Бурятии. Глава 2 «Буддийское духовенство Монголии» посвящена его становлению, социальной структуре, связям с Тибетом. Наиболее известные представители монгольского духовенства составляют предмет раздела 2.1. данной главы. Раздел 2.2. посвящен хубилганам и хутухтам в истории монгольского буддизма. Следующий за ним раздел содержит список и краткие биографические данные о 19 перерожденных ламах, признаваемых в Монголии (по данным на 2015 г.).

Часть 3 «Монгольские монастыри» открывается главой 1 «Монгольские монастыри: особенности и своеобразие», которая посвящена развитию монастырей Монголии, их типологии, структуре и т. д. Глава 2 «Их-хурэ: Зун-хурэ и Гандан» посвящена двум главным монастырям столицы Монголии, нормативным актам, которыми монастыри руководствовались в прошлом и руководствуются в настоящем. Отдельно выделенный раздел 2.1. посвящен наиболее крупным монастырям Монголии: Эрдэнэ-Дзу, Зун-хурэ, Сарьдагин-хийд, Гандантэгченлин, дворец-музей Богдо-гэгэна, Чойжин-ламын-сумэ, Дамбадаржа-хийд, Хамрийн-хийд, Манджушри-хийд, Тувхин-хийд, Сангийн-Далай, Увгун-хийд, Заяийн-хурэ, Амарбаясгалант, Угтаалсангийн Далайхийд, Шанхын-хийд, Дэчингалбын-сумэ. В разделе 2.2. «Новые монастыри и храмы» приведены сведения о трех новых буддийских монастырях Монголии. 
В «Заключении» обобщаются данные предыдущих глав. На основе этого автор справедливо заключает, что «на сегодняшний день буддийская религия глубоко впиталась в бытие, культуру, психику, национальное самосознание монголов, и в качестве хранительницы традиций служит одним из основных векторов стабильности общества» [Ванчикова 2019: 229].

Список литературы и источников составляют около 360 работ на русском, монгольском и западноевропейских языках. Кроме того, использовано 23 электронных источника.

В приложении даются цветные и черно-белые фотографии буддийских изображений, книг, монастырей, лам и др. Имеется именной указатель. Приложена цветная карта монастырей и храмов Монголии в начале XX в.

Наряду со многими достоинствами, работа не лишена отдельных недочетов. Упоминаются «монгольская династия Юань в Китае», «маньчжурские императоры Китая», «маньчжуро-цинская династия Китая» [Ванчикова 2019: 5051]. В действительности Китай, присоединенный монголами, а затем маньчжурами к их империям, стал лишь одной из их частей (подробнее см.: [Дмитриев, Кузьмин 2014: 5-17]). Соответственно, в отношениях с госорганами церковь Монголии руководствовалась правилами, составленными и утвержденными не китайским [Ванчикова 2019: 191], а цинским правительством.

Шабинары обозначены как «крепостные подданные» [Ванчикова 2019: 55]. Однако статус шабинаров ни формально, ни фактически не соответствует статусу крепостных (подробнее см.: [Кузьмин 2018: 23-30]).

Личные титулы (Далай-лама, Панчен-лама, Богдо-гэгэн, Джебцзундамба-хутухта) написаны со строчной буквы. Однако такие титулы аналогичны именам и фамилиям, которые пишутся с прописной буквы. При этом некоторые другие личные титулы автор обоснованно пишет с большой буквы (Пагба-лама, Майдари-хутухта, Зая-пандита, Ламын-гэгэн; на с. 169-173 даны списки перерожденных лам, титулы которых тоже написаны с большой буквы). На с. 34 сказано, что во главе иерархии Гэлуг в Тибете были Далай-лама и Панчен-лама. В действительности главой Гэлуг является Ганден-трипа. «Установлению Монгольского теократического государства способствовал и внешний фактор: Синьхайская революция, которая привела к падению Цинской империи и провозглашению Китайской Народной Республики» [Ванчикова 2019: 64]. В 1912 г. была провозглашена Китайская республика, а не КНР. «Сразу же после освобождения Урги» - читаем на с. 67. Занятие Урги красными войсками не было ее освобождением. Наконец, Богдо-гэгэн IX не был назначен монгольским президентом главой монгольских буддистов [Ванчикова 2019: 137] — президент лишь констатировал уже произошедшее подтверждение его в этом качестве.

Сделанные замечания не снижают общей высокой научной ценности данной работы. Следует отметить глубокую проработку ее автором поставленной проблемы. Данная работа вводит новые, до сих пор неизвестные или малоизвестные материалы в научный оборот. В целом ее следует признать важным вкладом в монголоведение и религиоведение, открывающим новые горизонты для исследований по истории буддизма в Монголии. Эта монография представляет интерес не только для исследователей буддизма Монголии, но и для 


\section{Рецензия}

всех, кто интересуется историей этой страны и динамикой политической ситуации в ней.

\section{Литература}

Батсайхан 2011 - Батсайхан O. Монголын сүүлчийн эзэн хаан VIII Богд Жавзандамба (= Последний монгольский великий хан Богдо VIII Джебцзундамба). Улаанбаатар: Адмон, 2011. 708 с.

Ванчикова 2019 - Ванчикова Ц. П. Буддизм в Монголии: история, духовенство, монастыри. Иркутск: Оттиск, 2019. 292 с.

Дмитриев, Кузьмин 2014 - Дмитриев С. В., Кузьмин С. Л. Империя Цин как Китай: анатомия исторического мифа // Восток. 2014. № 1. С. 5-17.

Кузьмин 2016 - Кузьмин С. Л. Теократическая государственность и буддийская церковь Монголии в начале ХХ века. М.: КМК, 2016. 496 с.

Кузьмин 2018 - Кузьмин С. Л. К вопросу о «крепостных церковных феодалов» в дореволюционной Монголии // Восток. 2018. № 1. С. 23-30.

Монголын сүм 2009 - Монголын сүм хийдийн түүхэн товчоон (= Краткая история храмов и монастырей Монголии) / ред. С. Цэдэндамба. Улаанбаатар: Адмон, 2009. $888 \mathrm{c}$.

Монголын сүм 2012 - Монголын сүм хийдийн түүхээс... (= Из истории храмов и монастырей Монголии) / сост. Б. Эрдэнэбилэг, Ш. Сонинбаяр, Н. Амгалан. Улаанбаатар: Тагнуулын Ерөнхий Газрын хэвлэх хэсэгт хэвлэв, 2012. 341 с.

Мягмарсамбуу 2014 - Мягмарсамбуу Г. Монголын шашин, төрийн нэрт зүтгэлтэн Егүзэр хутагт Жамсранжавын Галсандаш (1870-1930) (= Известный религиозный и государственный деятель Монголии Егузэр-хутухта Джамсранжавын Галсандаш (1870-1930)). Улаанбаатар: Соёмбо принтинг, 2014. 270 с.

Позднеев 1880 - Позднеев А. М. Ургинские хутухты. Исторический очерк их прошлого и современного быта. СПб.: тип. Пантелеевых, 1879 (1880). 84 с.

Позднеев 1887 - Позднеев А. М. Очерки быта буддийских монастырей и буддийского духовенства в Монголии, в связи с отношениями сего последнего к народу. СПб.: тип. Имп. академии наук, 1887. 510 с.

Пүрэвжав, Дашжамц 1965 - Пүрэвжав С., Дашжами Д. БНМАУ-д сум, хийд, лам нарынасуудлыгшийдвэрлэсэннь. 1921-1940 он (= Решение вопроса о монастырях, храмах и ламах в МНР. 1921-1940 гг.). Улаанбаатар: Улсын хэвлэлийн хэрэгэрхлэх хороо, $1965.262 \mathrm{c}$.

Скрынникова 1988 - Скрынникова Т. Д. Ламаистская церковь и государство. Внешняя Монголия XVI - начало XX в. Новосибирск: Наука, 1988. 104 с.

\section{References}

Batsaikhan O. $8^{\text {th }}$ Bogd Jebtsundamba Khutukhtu: the Last Great Khan of Mongolia. Ulaanbaatar: Admon, 2011. 708 p. (In Mong.)

Dmitriev S. V., Kuzmin S. L. Qing Empire as China: anatomy of a historical myth. Oriens. 2014. No. 1. Pp. 5-17. (In Russ.)

Erdenebileg B., Soninbayar Sh., Amgalan N. (comps.) Temples and Monasteries of Mongolia: Glimpses of History. Ulaanbaatar: General Intelligence Agency of Mongolia, 2012. 341 p. (In Mong.)

Kuzmin S. L. Mongolia in the Early $20^{\text {th }}$ Century: Theocratic State and Buddhist Church. Moscow: KMK, 2016. 496 p. (In Russ.)

Kuzmin S. L. On the problem of the 'serfs of clerical lords' in pre-revolutionary Mongolia. Oriens. 2018. No. 1. Pp. 23-30. (In Russ.)

Myagmarsambuu G. Eguzer Khutuktu Jamsranjavyn Galsandash (1870-1930), a Renowned 
Religious Leader and Government Official. Ulaanbaatar: Soembo Printing, 2014. 270 p. (In Mong.)

Pozdneev A. M. Essays on the Life of Buddhist Monasteries and Buddhist Clergy in Mongolia, and Relations of the Latter to the People. St. Petersburg: Imperial Academy of Sciences, 1887. 510 p. (In Russ.)

Pozdneev A. M. Khutukhtus of Urga: a Historical Essay on Their Past and Present Life. St. Petersburg: Panteleevy, 1879 (1880). 84 p. (In Russ.)

Pürevzhav S., Dashzhamts D. Mongolian People's Republic, 1921-1940: Resolving the Question of Monasteries, Temples, and Lamas. Ulaanbaatar: State Executive Publishing Committee, 1965. 262 p. (In Mong.)

Skrynnikova T. D. Outer Mongolia, $16^{\text {th }}$ to Early $20^{\text {th }}$ Centuries: Lamaist Church and State. Novosibirsk: Nauka, 1988. 104 p. (In Russ.)

Tsedendamba S. (ed.) A Brief History of Mongolian Temples and Monasteries. Ulaanbaatar: Admon, 2009. 888 p. (In Mong.)

Vanchikova Ts. P. Buddhism in Mongolia: History, Clergy, Monasteries. Irkutsk: Ottisk, 2019. 292 p. (In Russ.) 